\title{
Variation of Anatomical Characteristics within the Culm of the Three Gigantochloa Species from Indonesia
}

\author{
Muhammad Iqbal Maulana, ${ }^{\mathrm{a}, \#}$ Woo Seok Jeon,,${ }^{\mathrm{b}, \mathrm{c}, \#}$ Byantara Darsan Purusatama, \\ Deded Sarip Nawawi, ${ }^{a}$ Siti Nikmatin,,${ }^{\text {,e }}$ Rita Kartika Sari, ${ }^{a}$ Wahyu Hidayat, ${ }^{f}$ \\ Fauzi Febrianto, ${ }^{\mathrm{a}, *}$ Jong Ho Kim, ${ }^{\mathrm{b}}$ Seung Hwan Lee, ${ }^{\mathrm{b}}$ and Nam Hun Kim ${ }^{\mathrm{b}, *}$
}

\begin{abstract}
The anatomical features of three valuable commercial Gigantochloa bamboo species growing in Indonesia, including G. pseudoarundinacea, G. apus, and G. atroviolacea, were investigated by optical microscopy. The relative crystallinity and crystalline width of the culm of the bamboo species were examined by an X-ray diffraction method. These species contained vascular bundle of type III. Vascular bundle density was higher in the outer part of bamboo culm than in the inner. Fiber portion decreased from the outer part to the inner part and vice versa for the parenchyma and vessel portions. Fiber length of all species was higher in the outer part than the inner part of the culm. There was a significant difference in the fiber percentage between the bamboo species. Significant differences were also found in vessel diameter and parenchyma cell dimensions among the bamboo species. There was a slight difference in the crystalline properties between the outer and inner parts of the culm and among the bamboo species. All parameters showed a variation in the radial direction of the three bamboo culm but did not show a consistent tendency along the vertical direction.
\end{abstract}

Keywords: Bamboo anatomy; Cell proportion; Gigantochloa; Relative crystallinity; Vascular bundle

Contact information: a: Department of Forest Products, Faculty of Forestry and Environment, IPB University (Bogor Agricultural University), Bogor 16680, Indonesia; $b$ : Department of Forest Biomaterials Engineering, College of Forest and Environmental Science, Kangwon National University, Chuncheon 24341, Republic of Korea; : Division of Timber Engineering, National Institute of Forest Science, Seoul 02455, Republic of Korea; d: Department of Physics, Faculty of Mathematics and Natural Sciences, IPB University (Bogor Agricultural University), Bogor 16680, Indonesia; e: Surfactant and Bioenergy Research Center, IPB University (Bogor Agricultural University), Bogor 16143, Indonesia; f: Department of Forestry, Faculty of Agriculture, University of Lampung, Bandar Lampung 35145, Indonesia; \# The first two authors contributed equally to this work;

* Corresponding authors: febrianto76@yahoo.com; kimnh@kangwon.ac.kr

\section{INTRODUCTION}

Bamboos encompass a broad group of 1,250 species within 75 genera, most of which are relatively fast-growing in various types of soil, attaining stand maturity within five years. The stands of tall species may reach $15 \mathrm{~m}$ to $20 \mathrm{~m}$, and the largest species, Dendrocalamus giganteus, grows to $40 \mathrm{~m}$ in height and $30 \mathrm{~cm}$ in culm diameter (Scurlock et al. 2000). The main distribution of bamboo comprises Africa and America, with $80 \%$ of the bamboo found in Asia Pacific including Indonesia (Mera and Xu 2014). Bamboo plays important roles in the lives of various peoples of the world. It is estimated that more than 2.5 billion people depend on bamboo for their economy and one billion people live in traditional bamboo houses (Lobovikov et al. 2007). Several studies show the potential of bamboo as an alternative to wood composite materials (Febrianto et al. 2012, 2015; 
Hidayat et al. 2019; Maulana et al. 2019) and as a fuel source or biomass energy raw material (Park et al. 2018, 2019, 2020).

In Indonesia, there are 161 species of bamboo grown, 126 species of which are endemic (Widjaja et al. 2014). Gigantochloa is one of these endemic bamboo genera and is mostly found in Java and Sumatra. Gigantochloa pseudoarundinacea, G. apus, and G. atroviolacea are found only in cultivation and locally known as Andong, Tali, and Hitam bamboo, respectively. They are commonly used in the bamboo industry together with Dendrocalamus asper, Bambusa blumeana, and Schizostachyum brachycladum. In particular, G. pseudoarundinacea is a potential raw material for oriented strand board (Febrianto et al. 2015), while G. apus and G. atroviolacea are more suitable for composite beam (Cahyono et al. 2014).

Although these species have been used in various applications, information regarding the anatomical characteristics of the bamboo culms of Gigantochloa genus are very limited. Mustafa et al. (2011) reported that four species of Gigantochloa from Malaysia had different vascular bundle sizes and fiber morphology between species and along the horizontal position in the culms of each species. Nordahlia et al. (2012) reported that fiber length in Gigantochloa levis was not significantly affected by culm age; however, it was affected by culm height. Similar trends in the fiber length of Gigantochloa atter were also reported by Marsoem et al. (2015).

In this study, therefore, the anatomical characteristics in radial and axial directions of the culms of the three commercial bamboo species growing in Java, Indonesia, including G. pseudoarundinacea, G. apus, and G. atroviolacea, were investigated to give further valuable insight for effective utilization of such bamboo resources.

\section{EXPERIMENTAL}

\section{Materials}

The three culms of 5-year-old Andong (G. pseudoarundinacea), Tali (G. apus), and Hitam bamboo ( $G$. atroviolacea) were harvested from the bamboo garden of the Center for Research and Development (P3) Biomaterials, Indonesian Institute of Sciences, Cibinong, Bogor, Indonesia. The culms were cut at the second node above the ground and the branched top parts were removed, leaving three-quarters of the total culm height. These culms were divided into three equal-length parts consisting of top, middle, and bottom sections as per SNI 8020:2014 (2014). Information regarding the three bamboo species is shown in Table 1.

Table 1. General Morphological Information of the Three Gigantochloa Bamboo Species

\begin{tabular}{|c|c|c|c|c|c|c|c|c|c|}
\hline & \multicolumn{3}{|c|}{ G. pseudoarundinacea } & \multicolumn{3}{|c|}{ G. apus } & \multicolumn{3}{|c|}{ G. atroviolacea } \\
\hline & Top & Middle & Bottom & Top & Middle & Bottom & Top & Middle & Bottom \\
\hline $\begin{array}{l}\text { Diameter } \\
(\mathrm{mm})\end{array}$ & $\begin{array}{c}68 \pm \\
0.8\end{array}$ & $\begin{array}{c}87 \pm \\
0.8\end{array}$ & $\begin{array}{c}94 \pm \\
1.6\end{array}$ & $\begin{array}{c}84 \pm \\
0.7\end{array}$ & $\begin{array}{c}88 \pm \\
0.6\end{array}$ & $86 \pm 1.2$ & $\begin{array}{c}48 \pm \\
0.1\end{array}$ & $\begin{array}{c}62 \pm \\
0.8\end{array}$ & $65 \pm 1.6$ \\
\hline $\begin{array}{l}\text { Culm } \\
\text { Thickness } \\
\text { (mm) }\end{array}$ & $\begin{array}{c}6.5 \pm \\
0.2\end{array}$ & $\begin{array}{c}9.2 \pm \\
0.3\end{array}$ & $\begin{array}{c}13.7 \pm \\
1.2\end{array}$ & $\begin{array}{c}11.5 \\
\pm \\
0.2\end{array}$ & $\begin{array}{c}12.5 \pm \\
0.4\end{array}$ & $\begin{array}{c}14.2 \pm \\
1.0\end{array}$ & $\begin{array}{c}4.4 \\
\pm \\
0.2\end{array}$ & $\begin{array}{c}6.2 \pm \\
0.5\end{array}$ & $\begin{array}{c}9.4 \pm \\
1.0\end{array}$ \\
\hline Height $(\mathrm{m})$ & \multicolumn{3}{|c|}{$16.1 \pm 2.1$} & \multicolumn{3}{|c|}{$16.0 \pm 0.8$} & \multicolumn{3}{|c|}{$15.6 \pm 1.8$} \\
\hline
\end{tabular}




\section{Optical Microscopy}

Anatomical characteristics of the bamboo species, such as vascular bundle type, vascular bundle density, fiber length, parenchymal dimensions, vessel diameter, and percentage of cell types were observed using an optical microscope (Nikon Eclipse E600, Tokyo, Japan) and an image analyzer (IMT i-solution lite, Version 9.1, British Columbia, Canada). Bamboo blocks were first softened in a boiling mixture of glycerin and water (50:50), and then sliced with a rotary microtome (Leica RM 2165, Wetzlar, Germany). The sections were stained with a $1 \%$ safranin solution and $1 \%$ Light Green SF yellowish solution and dehydrated with ethanol series $(50 \%, 70 \%, 90 \%, 95 \%$, and 99\%) and xylene (Jeon et al. 2018a). The permanent slides were obtained using Canada balsam resin. For fiber length measurements, match-sized bamboo slivers were macerated with a mixed solution of glacial $\mathrm{H}_{2} \mathrm{O}_{2}$ and $\mathrm{CH}_{3} \mathrm{COOH}$ with a ratio of $1: 1(\mathrm{v} / \mathrm{v})$ and then heated at $60{ }^{\circ} \mathrm{C}$ until defibrillation (Franklin 1945).

In this study, the vascular bundle density was measured in the area of $4 \mathrm{~mm}^{2}$. The percentage of cell types was determined as the proportion of the area of each cell type per the total area of the optical micrographs at $4 \mathrm{x}$ magnification. Data for vascular bundle density and percentage of cell types were collected 10 times and 5 times, respectively. The dimension of fiber, vessel, and parenchyma cells was measured with 40 replications.

\section{X-ray Diffraction Analysis}

Equatorial X-ray diffractograms in reflection mode were obtained using X-ray diffraction (Cu target, DMAX 2100V, Rigaku, Tokyo, Japan, 40 kV, $40 \mathrm{~mA}$ ) installed at the Institute of Forest Science, Kangwon National University, Chuncheon, Korea. The relative crystallinity and crystallite width of the bamboo culms were analyzed using Segal's method (Segal et al. 1959) and Scherrer's equation (Burton et al. 2009), respectively.

\section{Data Analysis}

Analysis of variance and Duncan multiple range test were applied to test the significance of vascular bundle density, cells dimension, and cells proportion of the bamboo species using IBM SPSS Statistics, Version 21 (IBM, Armonk, NY, USA).

\section{RESULTS AND DISCUSSION}

\section{Characteristics of Vascular Bundles}

Figure 1 shows the cross-section of the three Gigantochloa bamboo samples consisted of vascular bundles and ground parenchyma. The shape or pattern of vascular bundles in bamboo species is classified into 4 types (Liese 1980). Tropical bamboo generally has vascular bundles of types III and IV (Grosser and Liese 1971). Microscopic observations on the three bamboo species showed the vascular bundle of type III. This vascular bundle type consists of one vascular central strand and one fiber strand.

Table 2 shows the vascular bundle density of the three Gigantochloa bamboo species. Vascular bundle density in the outer part of the bamboo culms was higher than that in the inner part. However, there were almost no changes and no fixed tendency of vascular bundle density in the vertical direction. In addition, there were significant differences in vascular bundle density in the horizontal direction of the bamboos. Vascular bundle density of Tali (G. apus) bamboo was significantly different from the Andong $(G$. pseudoarundinacea), and Hitam (G. atroviolacea) bamboo species. 


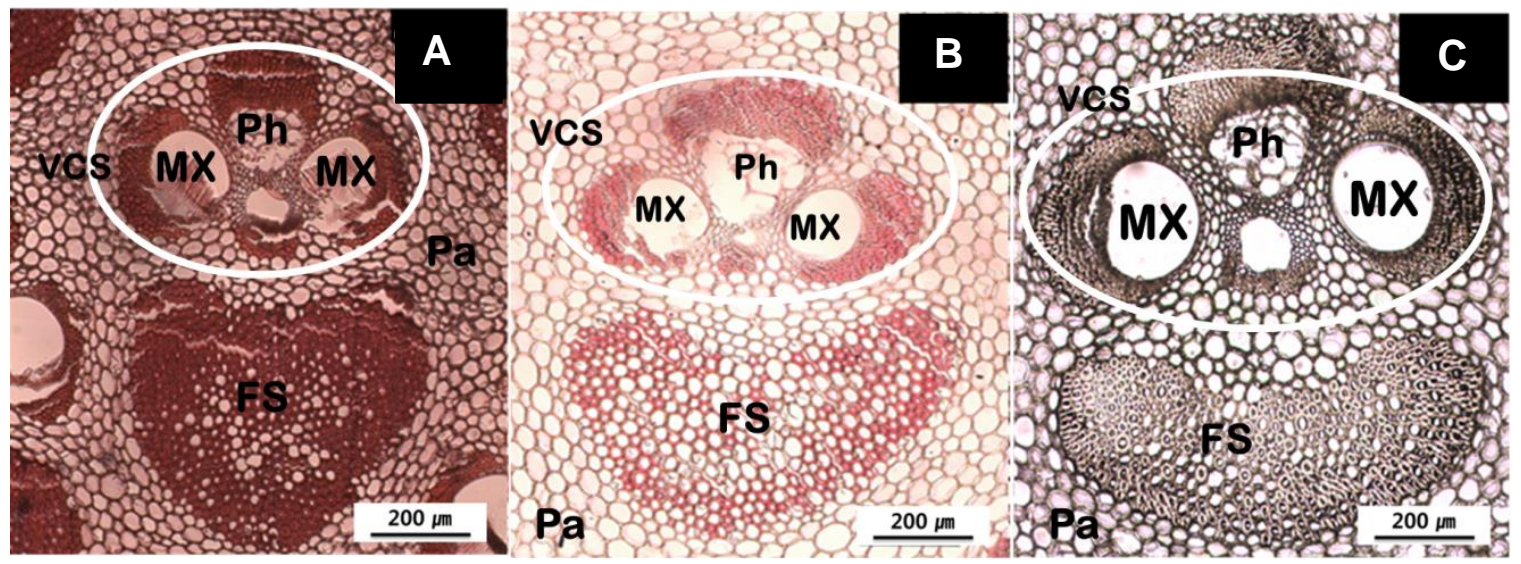

Fig. 1. Vascular bundles in the cross-sections of G. pseudoarundinacea (A), G. apus (B), and $G$. atroviolacea $(C)$; VCS: vascular central strand, Pa: parenchyma cells, FS: fiber strand, MX: metaxylem vessels, $\mathrm{Ph}$ : phloem vessels

Table 2. Vascular Bundle Density (Number/4 $\mathrm{mm}^{2}$ ) in the Three Gigantochloa Bamboo Species

\begin{tabular}{|c|c|c|c|c|c|c|c|c|}
\hline \multirow{2}{*}{ Species } & \multicolumn{4}{|c|}{ Outer Part } & \multicolumn{4}{c|}{ Inner Part } \\
\cline { 2 - 10 } & Top & Middle & $\begin{array}{c}\text { Botto } \\
\mathrm{m}\end{array}$ & Mean & Top & Middle & Bottom & Mean \\
\hline G. & $15 \pm$ & $15 \pm$ & $15 \pm$ & $15 \pm$ & $6 \pm$ & $5 \pm$ & $4 \pm$ & $5 \pm$ \\
pseudoarundinacea & 1.1 & 0.9 & 0.8 & $0.9^{\mathrm{Ab}}$ & 0.8 & 1.1 & 0.5 & $1.1^{\mathrm{Ba}}$ \\
\hline \multirow{2}{*}{ G. apus } & $17 \pm$ & $17 \pm$ & $16 \pm$ & $17 \pm$ & $4 \pm$ & $4 \pm$ & $4 \pm$ & $4 \pm$ \\
& 2.0 & 2.4 & 1.5 & $2.0^{\mathrm{Bb}}$ & 0.5 & 0.5 & 0.7 & $0.5^{\mathrm{Aa}}$ \\
\hline \multirow{2}{*}{ G. atroviolacea } & $13 \pm$ & $15 \pm$ & $14 \pm$ & $14 \pm$ & $6 \pm$ & $6 \pm$ & $4 \pm$ & $5 \pm$ \\
& 1.5 & 2.9 & 1.2 & $2.1^{\mathrm{Ab}}$ & 0.8 & 0.7 & 0.7 & $1.0^{\mathrm{Ba}}$ \\
\hline
\end{tabular}

Notes: Numbers in the same column followed by different capital letters are significantly different at $5 \%$ level. Numbers in the same row followed by different lower case letters are different at $5 \%$ significant level.

The significant difference in vascular bundle density between the inner and outer parts may be due to the increasing size of the vascular bundles in the inner part of the culm; thus, the number per unit area was decreased. Several studies have shown a similar trend in vascular bundle density along the horizontal position. Mustafa et al. (2011) found that number of vascular bundles of various Malaysian Gigantochloa species decreased from the outer part to the inner part of the culm, both in the node and internode. Vascular bundle number near epidermis of the culm of Phyllostachys pubescens was higher than that in the near pith part (Jeon et al. 2018b). Quite recently, Darwis et al. (2020) reported using a nonlinear regression equation that the number of vascular bundles in the culm of G. pruriens decreased from the outer layer to the inner.

\section{Cell Proportions}

Table 3 shows the cell proportions of the three Gigantochloa bamboo species. Bamboo species and horizontal position have a significant effect on the proportion of each cell. The percentage of fiber cells in the outer part was higher than that in the inner part, but parenchyma and vessels in the outer part were of lower portion than the inner part for all three of the bamboo species. Andong ( $G$. pseudoarundinacea) bamboo showed the lowest fiber percentage and highest parenchyma proportion among the three species 
studied. Vessel portion in the inner part of Hitam (G. atroviolacea) bamboo showed a somewhat higher value compared to the other bamboo species. Meanwhile, differences in vertical position on fiber and parenchyma cell portion do not show a consistent tendency for all bamboo species. Vessel cell portion tended to increase from the bottom culm to the top culm position. Darwis et al. (2020) reported a similar trend in G. pruriens, with an increase in the parenchyma percentage from the outer to the inner part and vice versa for the vascular bundles. They also reported that parenchyma percentage in the bottom position was lower than that in the middle and top positions. The different portions in the outer and inner part of the culm could be due to different vascular bundle densities. Because the vascular bundle frequency decreases in the inner part, parenchyma ground tissue would occupy more space (Huang et al. 2015).

Table 3. Cell Proportion (\%) of the Three Gigantochloa Bamboo Species

\begin{tabular}{|c|c|c|c|c|c|c|c|}
\hline \multirow{2}{*}{ Species } & \multirow{2}{*}{ Position } & \multicolumn{2}{|c|}{ Fiber } & \multicolumn{2}{|c|}{ Parenchyma } & \multicolumn{2}{|c|}{ Vessel } \\
\hline & & Outer & Inner & Outer & Inner & Outer & Inner \\
\hline \multirow{4}{*}{$\begin{array}{l}\text { G. } \\
\text { pseudoarundin } \\
\text { acea }\end{array}$} & Top & $49 \pm \underset{A}{ \pm} 1.4$ & $29 \pm \underset{A}{ } 3.5$ & $42 \pm \frac{A}{A} 1.6$ & $61 \underset{A B}{ \pm 1.9}$ & $8 \pm \underset{A}{0.9}$ & $11 \pm 2.3$ \\
\hline & Middle & $52 \pm \frac{A}{A} 1.6$ & $31 \pm \underset{A}{ } 1.3$ & $41 \pm \underset{A}{A} 1.8$ & $60 \pm \frac{A}{A} 1.8$ & $7 \underset{A}{ \pm 0.3}$ & $\underset{A}{9 \pm 0.9}$ \\
\hline & Bottom & $52 \pm \frac{A}{A} .3$ & $29 \pm \frac{A}{A} 1.2$ & $41 \pm \frac{ \pm}{A} 2.1$ & $63 \pm \frac{1.2}{B}$ & $7 \pm 0.2^{A}$ & $8 \pm 0.6^{A}$ \\
\hline & Mean & $51 \pm 2.2$ & $30 \pm \underset{\mathrm{Aa}}{ \pm 2.3}$ & $41 \pm \underset{\mathrm{Ba}}{ \pm 1.7}$ & $61 \pm \underset{A b}{ \pm 2.2}$ & $7 \underset{\mathrm{Aa}}{7 \pm 0.9}$ & $9 \underset{\mathrm{ABa}}{9 \pm 1.8}$ \\
\hline \multirow{4}{*}{ G. apus } & Top & $54 \underset{A}{ \pm} 1.4$ & $30 \pm \frac{B}{B} 1.4$ & $39 \pm \frac{B}{B} 1.2$ & $62 \pm \underset{A}{ } 2.2$ & $7 \pm \underset{A}{0} 0.7$ & $\underset{A}{8 \pm 1.0}$ \\
\hline & Middle & $57 \underset{B}{ \pm 0.5}$ & $32 \pm \frac{c}{c} 0.8$ & $37 \pm \frac{A}{A} 1.1$ & $59 \pm \frac{A}{A} 2.3$ & $6 \pm \underset{A}{0.6}$ & $8 \pm \underset{A}{1.7}$ \\
\hline & Bottom & $58 \pm \frac{B}{B} 0.9$ & $27 \underset{\mathrm{A}}{ \pm} 0.9$ & $36 \underset{A}{ \pm} 1.1$ & $66 \pm \frac{B}{B} 1.3$ & $\underset{A}{6 \pm 0.3}$ & $\underset{A}{7 \pm 0.9}$ \\
\hline & Mean & $57 \underset{\mathrm{Bb}}{ \pm 2.5}$ & $30 \underset{\mathrm{Aa}}{ \pm 2.4}$ & $37 \underset{\mathrm{Aa}}{ \pm 1.9}$ & $62 \pm \frac{A b}{A b} 3.3$ & $6 \underset{\mathrm{Aa}}{6 \pm 0.7}$ & $8 \pm \underset{A b}{1.3}$ \\
\hline \multirow{4}{*}{ G. atroviolacea } & Top & $62 \pm \underset{A}{ } 0.7$ & $29 \pm \underset{A}{ } 0.9$ & $28 \pm \frac{A}{A} 1.1$ & $58 \pm \underset{A}{ \pm} 1.5$ & $11 \pm \frac{ \pm}{c} 1.5$ & $13 \pm \frac{1}{B} 1.6$ \\
\hline & Middle & $54 \underset{A}{ \pm} 8.4$ & $29 \pm \frac{A}{A} 1.2$ & $41 \pm \frac{ \pm}{B} 8.0$ & $59 \pm \underset{A}{ } 0.6$ & $5 \pm 0.9^{B}$ & $12 \pm \frac{1.1}{B}$ \\
\hline & Bottom & $59 \pm \frac{A}{A} 1.4$ & $26 \pm \underset{A}{ } 2.5$ & $38 \pm \frac{B}{B} 1.7$ & $67 \pm \frac{2.8}{B}$ & $3 \pm \underset{A}{0.0 .5}$ & $7 \pm \underset{A}{0} 0.8$ \\
\hline & Mean & $58 \pm \frac{\mathrm{Bb}}{5.5}$ & $28 \pm \underset{\mathrm{Aa}}{ \pm 2.0}$ & $35 \underset{\mathrm{Aa}}{ \pm .3 .3}$ & $61 \pm \underset{\mathrm{Ab}}{ \pm} 4.4$ & $\underset{\mathrm{Aa}}{6 \pm 3.6}$ & $11 \underset{\mathrm{Bb}}{ \pm 2.9}$ \\
\hline \multicolumn{8}{|c|}{$\begin{array}{l}\text { Notes: Numbers in the same column followed by different capital letters are different at } 5 \% \\
\text { significant level among vertical position. Numbers in the same row followed by different lower } \\
\text { case letters are different at } 5 \% \text { significant level between outer and inner part for each type of } \\
\text { cell. }\end{array}$} \\
\hline
\end{tabular}

\section{Cells Dimensions}

Fiber lengths of the three Gigantochloa bamboo species are shown in Table 4. Fibers in the outer part of the bamboo culm were longer than those in the inner part. The analysis of variance showed that the bamboo species and horizontal position significantly influenced the fiber length. There was a significant difference in the length of the fibers between the outer and inner parts of the culm. However, this was not a consistent tendency in the fiber length along the vertical direction. In Tali bamboo, the middle part of bamboo 
culm had the lowest fiber length, while the highest fiber length was found in the middle part in Hitam bamboo. An increase of fiber length from the bottom to the top of the culm was found in Andong bamboo. Siam et al. (2019) reported fiber lengths of 13 Malaysian bamboo species, which decreased from the bottom to the top position. The variety in fiber length seen in the trend along the vertical position might depend on the species. Other research from India found that the longest fiber in the culm of Bambusa mizorameana was in the middle position and the shortest was in the bottom position (Kumar et al. 2017). In G. pruriens, the fiber length was reported to be the shortest in the inner and bottom of the culm (Darwis et al. 2020).

Table 4. Fiber Lengths $(\mu \mathrm{m})$ of the Three Gigantochloa Bamboo Species

\begin{tabular}{|c|c|c|c|c|c|c|c|c|}
\hline \multirow{2}{*}{ Species } & \multicolumn{4}{|c|}{ Outer } & \multicolumn{4}{c|}{ Inner } \\
\cline { 2 - 9 } & Top & Middle & Bottom & Mean & Top & Middle & Bottom & Mean \\
\hline G. & 2330 & 2413 & 2637 & 2460 & 2304 & 2353 & 2600 & 2419 \\
pseudoarundinacea & \pm 232 & \pm 395 & \pm 506 & $\pm 412^{\mathrm{Bb}}$ & \pm 285 & \pm 373 & \pm 428 & $\pm 383^{\mathrm{Ba}}$ \\
\hline \multirow{2}{*}{ G. apus } & 2404 & 2392 & 2457 & 2417 & 2321 & 2184 & 2408 & 2304 \\
& \pm 251 & \pm 342 & \pm 286 & $\pm 294^{\mathrm{Bb}}$ & \pm 210 & \pm 269 & \pm 294 & $\pm 272^{\mathrm{Ba}}$ \\
\hline \multirow{2}{*}{ G. atroviolacea } & 2085 & 2460 & 2373 & 2306 & 2071 & 2249 & 2150 & 2157 \\
& \pm 230 & \pm 581 & \pm 206 & $\pm 409^{\mathrm{Ab}}$ & \pm 150 & \pm 349 & \pm 247 & $\pm 267^{\mathrm{Aa}}$ \\
\hline
\end{tabular}

Notes: Numbers in the same column followed by different capital letters are different at $5 \%$ significant level. Numbers in the same row followed by different lower case letters are different at $5 \%$ significant level.

The vessel diameter of the outer part of Gigantochloa bamboo ranged from 173.1 $\mu \mathrm{m}$ to $308.1 \mu \mathrm{m}$ (Table 5). The largest vessel diameter was found in Andong bamboo, and there were significant differences in vessel diameters among the bamboo species. Jeon et al. (2018a) reported that vessel diameter of three Korean bamboos (Phyllostachys genera) ranged from $90.9 \mu \mathrm{m}$ to $117.9 \mu \mathrm{m}$, which were smaller in diameter compared to that found in this study. Although, comparable results for vessel diameter of G. pruriens, which ranged from $130 \mu \mathrm{m}$ to $197 \mu \mathrm{m}$ have been reported (Darwis et al. 2020).

Table 5. Dimensions of Vessel and Parenchyma $(\mu \mathrm{m})$ of the Three Gigantochloa Bamboos

\begin{tabular}{|c|c|c|c|c|}
\hline \multirow{2}{*}{ Characteristics } & \multirow{2}{*}{$\begin{array}{l}\text { Vessel Diameter } \\
\text { on the Outer Part }\end{array}$} & \multirow{2}{*}{$\begin{array}{c}\text { Parenchyma } \\
\text { Diameter on the } \\
\text { Outer Part }\end{array}$} & \multicolumn{2}{|c|}{ Parenchyma Length } \\
\hline & & & Radial & Tangential \\
\hline G. pseudoarundinacea & $308.1 \pm 40.8^{c}$ & $35.5 \pm 3.6^{a}$ & $\begin{array}{c}101.4 \pm \\
9.3^{\mathrm{Ab}}\end{array}$ & $\begin{array}{l}96.2 \pm \\
11.9^{A b} \\
\end{array}$ \\
\hline G. apus & $204.5 \pm 34.8^{b}$ & $36.7 \pm 9.4^{\mathrm{a}}$ & $\begin{array}{l}78.1 \pm \\
21.7^{\mathrm{Aa}}\end{array}$ & $\begin{array}{l}87.2 \pm \\
18.4^{\mathrm{Aa}}\end{array}$ \\
\hline G. atroviolacea & $173.1 \pm 30.4^{\mathrm{a}}$ & $39.5 \pm 3.8^{b}$ & $\begin{array}{c}120.4 \pm \\
10.9^{A c}\end{array}$ & $\begin{array}{c}125.0 \pm \\
9.8^{\mathrm{AC}}\end{array}$ \\
\hline
\end{tabular}

Figure 2 shows the optical micrographs of radial and tangential sections of the three Gigantochloa bamboos. The diameters of the parenchyma cells on the outer part in the cross-sections of three Gigantochloa bamboos was 35.5 to $39.5 \mu \mathrm{m}$ (Table 5). The lengths of parenchyma cells in the radial and tangential sections of the bamboos was 78.1 to 120.4 
$\mu \mathrm{m}$ and 87.2 to $125.0 \mu \mathrm{m}$, respectively. There was a significant difference in the parenchyma diameter of $G$. atroviolacea compared to the other bamboo species. Parenchyma lengths between bamboo species were also significantly different. However, parenchyma length between the radial and tangential sections in each bamboo species were not significantly different. Wahab et al. (2010) found that parenchyma cell diameter of Bambusa vulgaris grown in Malaysia was $23.3 \mu \mathrm{m}$ to $26.6 \mu \mathrm{m}$, which is lower than what was found in this study. Jeon et al. (2018a) reported that the diameter and length of parenchyma cells showed significant differences among three Phyllostachys bamboos.
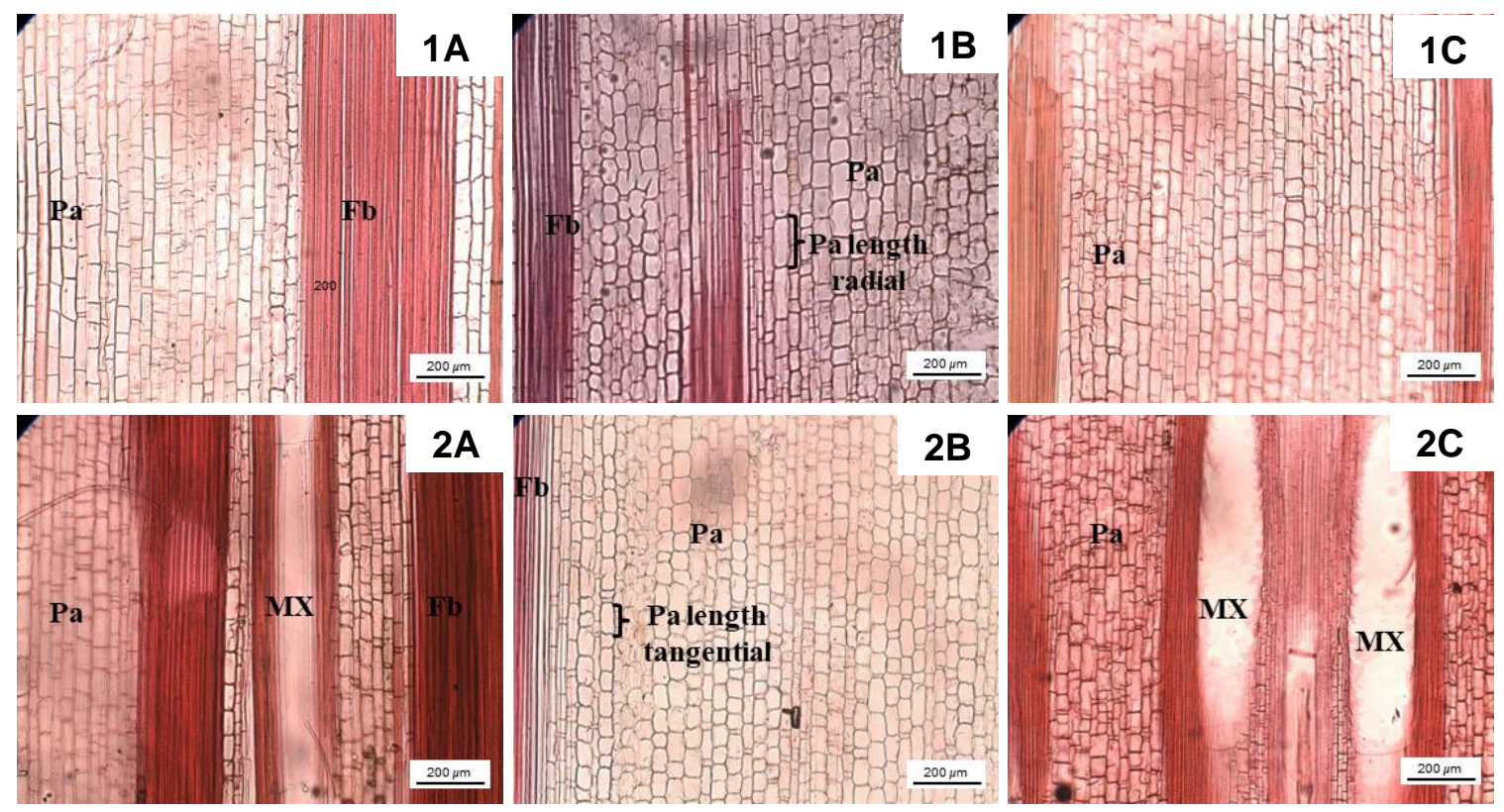

Fig. 2. Optical micrographs of radial (1A, $1 \mathrm{~B}$, and $1 \mathrm{C})$ and tangential $(2 \mathrm{~A}, 2 \mathrm{~B}$, and $2 \mathrm{C})$ sections of G. pseudoarundinacea (A), G. apus (B), and G. atroviolacea (C); Pa: parenchyma cells, MX: metaxylem vessels, Fb: Fiber bundles

\section{Relative Crystallinity}

Table 6 shows the crystalline properties in the culms of the three Gigantochloa bamboo species.

Table 6. Crystalline Properties of Three Gigantochloa Bamboo Species

\begin{tabular}{|c|c|c|c|c|c|c|c|c|c|}
\hline \multirow{2}{*}{ Species } & \multirow{2}{*}{ Position } & \multicolumn{4}{|c|}{ Relative Crystallinity (\%) } & \multicolumn{4}{|c|}{ Crystallite Width (nm) } \\
\hline & & Outer & Mean & Inner & Mean & Outer & Mean & Inner & Mean \\
\hline \multirow{3}{*}{$\begin{array}{c}\text { G. } \\
\text { pseudoarundinacea }\end{array}$} & Top & 78 & \multirow{3}{*}{$\begin{array}{l}81 \pm \\
2.3^{\mathrm{Ba}}\end{array}$} & 74 & \multirow{3}{*}{$\begin{array}{l}77 \pm \\
3.0^{\mathrm{Aa}}\end{array}$} & 3.9 & \multirow{3}{*}{$\begin{array}{c}4.1 \pm \\
0.16^{\mathrm{Bb}}\end{array}$} & 3.7 & \multirow{3}{*}{$\begin{array}{l}3.8 \pm \\
0.14^{\mathrm{Aa}}\end{array}$} \\
\hline & Middle & 82 & & 80 & & 4.1 & & 3.9 & \\
\hline & Bottom & 82 & & 77 & & 4.2 & & 3.9 & \\
\hline \multirow{3}{*}{ G. apus } & Top & 77 & \multirow{3}{*}{$\begin{array}{l}78 \pm \\
1.2^{\mathrm{ABb}}\end{array}$} & 74 & \multirow{3}{*}{$\begin{array}{l}73 \pm \\
0.6^{\mathrm{Aa}}\end{array}$} & 3.4 & \multirow{3}{*}{$\begin{array}{l}3.4 \pm \\
0.02^{\mathrm{Aa}}\end{array}$} & 3.3 & \multirow{3}{*}{$\begin{array}{l}3.3 \pm \\
0.05^{\mathrm{Aa}}\end{array}$} \\
\hline & Middle & 79 & & 74 & & 3.5 & & 3.3 & \\
\hline & Bottom & 77 & & 73 & & 3.4 & & 3.3 & \\
\hline \multirow{3}{*}{ G. atroviolacea } & Top & 74 & \multirow{3}{*}{$\begin{array}{l}75 \pm \\
2.3^{\mathrm{Aa}}\end{array}$} & 72 & \multirow{3}{*}{$\begin{array}{l}74 \pm \\
2.1^{\mathrm{Aa}}\end{array}$} & 3.8 & \multirow{3}{*}{$\begin{array}{l}4.0 \pm \\
0.16^{\mathrm{Ba}}\end{array}$} & 3.2 & \multirow{3}{*}{$\begin{array}{l}3.8 \pm \\
0.52^{\mathrm{Aa}}\end{array}$} \\
\hline & Middle & 78 & & 76 & & 4.0 & & 4.1 & \\
\hline & Bottom & 74 & & 73 & & 4.1 & & 4.0 & \\
\hline
\end{tabular}

Notes: Numbers in the same column followed by different capital letters are different at $5 \%$ significant level. Numbers in the same row followed by different lower case letters are different at $5 \%$ significant level. 
The relative crystallinity and crystallite width in the outer part were higher than those in the inner part of the bamboos. There were some differences in the crystalline properties between the bamboo species. Andong bamboo had the highest relative crystallinity, while Hitam bamboo had the lowest. The smallest crystallite width was found in Tali bamboo.

Jeon et al. (2018a) reported comparable values in relative crystallinity from three Phyllostachys bamboo species. They also observed a similar trend along radial direction as was noted in the present study. This tendency could be caused by the higher vascular bundle density and fiber percentage in the outer parts compared to the inner parts of the bamboo culm. Other studies have shown higher crystallite width in tropical bamboo. Brito et al. (2012) showed that the crystallite width of Bambusa vulgaris was $5.7 \mathrm{~nm}$. A similar crystallite width of $5.59 \mathrm{~nm}$ was also found in Dendrocalamus asper (Fatriasari et al. 2014). However, a study on temperate bamboo showed a similar trend in crystallite width along the horizontal position as found in this study. Wang et al. (2012) found that crystallite width of Phyllostachys edulis planted in China increased from about $2.9 \mathrm{~nm}$ in the inner part of the culm to $3.1 \mathrm{~nm}$ in the outer part. Crystallite widths of three Phyllostachys bamboos also increased from the inner part to the outer part of the culm; however, a consistent trend was not found among the three bamboos in the vertical position (Jeon $e t$ al. 2018a, 2018b).

\section{CONCLUSIONS}

1. The Gigantochloa pseudoarundinacea, G. apus, and G. atroviolacea bamboo had the vascular bundle of type III.

2. Vascular bundle density in bamboo culms was higher in the outer part than that of the inner part. There was a significant difference in the vascular bundle density in the radial direction among the bamboo species.

3. Fiber portion decreased from the outer part to the inner part and vice versa in the case of parenchyma and vessel portions. There was a significant difference in fiber percentage between the bamboo species. Vessel portion in Hitam bamboo showed a somewhat higher value compare to the other two bamboo species.

4. Fiber length in the outer part of culms was longer than that in the inner part. Andong bamboo had the largest fiber length and vessel diameter. There was a significant difference in fiber length between the outer and inner parts in the bamboo culms. Significant differences were also found in vessel diameter and parenchyma cell dimension among the bamboo species.

5. There was a slight difference in the relative crystallinity and crystallite width between the outer and inner parts of the culm and among the bamboo species.

6. All parameters showed a variation in the radial direction of the three bamboo culms but did not show a consistent tendency in the vertical direction.

In conclusion, it is revealed that vascular bundle density, vessel diameter, and parenchyma cell length can be used to identify the species among the three Gigantochloa bamboo species. 


\section{ACKNOWLEDGMENTS}

The authors sincerely acknowledge the Doctoral Program for Outstanding Undergraduate Students (PMDSU) Research Grant (No. 4122/IT3.L1/PN/2020) and Basic Research (PDUPT) Grant (No. 4033/IT3.L1/PN/2020) from Deputy of Strengthening for Research and Development, Ministry of Research and Technology/National Research and Innovation Agency, Republic of Indonesia for to the financial support. This study was also supported by the Science and Technology Support Program through the National Research Foundation of Korea (NRF) funded by the Ministry of Science and ICT (MSIT) (NRF2019K1A3A9A01000018) and the Basic Science Research Program via NRF funded by the Ministry of Education (No. 2016R1D1A1B01008339 and 2018R1A6A1A03025582).

\section{REFERENCES CITED}

Brito, B. S., Pereira, F. V., Putaux, J. L., and Jean, B. (2012). "Preparation, morphology and structure of cellulose nanocrystals from bamboo fibers," Cellulose 19(5), 15271536. DOI: $10.1007 / \mathrm{s} 10570-012-9738-9$

Burton, A. W., Ong, K., Rea, T., and Chan, I. Y. (2009). "On the estimation of average crystallite size of zeolites from the Scherrer equation: A critical evaluation of its application to zeolites with one-dimensional pore systems," Microporous and Mesoporous Materials 117(1-2), 75-90. DOI: 10.1016/j.micromeso.2008.06.010

Cahyono, T. D., Novriyanti, E., Bahtiar, E. T., and Massijaya, M. Y. (2014).

"Development of composite beams made from tali (Gigantochloa apus) and hitam bamboo (Gigantochloa atroviolacea)," Journal of the Indian Academy of Wood Science 11(2), 156-161. DOI: 10.1007/s13196-014-0131-1

Darwis, A., Iswanto, A. H., Jeon, W. S., Kim, N. H., Wirjosentono, B., Susilowati, A., and Hartono, R. (2020). "Variation of quantitative anatomical characteristics in the culm of belangke bamboo (Gigantochloa pruriens)," BioResources 15(3) 6617-6626. DOI: 10.15376/biores.15.3.6617-6626

Fatriasari, W., Syafii, W., Wistara, N. J., Syamsu, K., and Prasetya, B. (2014). "The characteristic changes of betung bamboo (Dendrocalamus asper) pretreated by fungal pretreatment," International Journal of Renewable Energy Development 3(2), 133143. DOI: $10.14710 /$ ijred.3.2.133-143

Febrianto, F., Hidayat, W., Bakar, E. S., Kwon, G. J., Kwon, J. H., Hong, S. I., and Kim, N. H. (2012). "Properties of oriented strand board made from Betung bamboo (Dendrocalamus asper (Schultes. f) Backer ex Heyne)," Wood Science and Technology 46(1-3), 53-62. DOI: 10.1007/s00226-010-0385-8

Febrianto, F., Jang, J. H., Lee, S. H., Santosa, I. A., Hidayat, W., Kwon, J. H., and Kim, N. H. (2015). "Effect of bamboo species and resin content on properties of oriented strand board prepared from steam-treated bamboo strands," BioResources 10(2), 2642-2655. DOI: 10.15376/biores.10.2.2642-2655

Franklin, G. L. (1945). "Preparation of thin sections of synthetic resins and wood-resin composites, and a new macerating method for wood," Nature 155(3924), 51-51. DOI: $10.1038 / 155051 \mathrm{a} 0$

Grosser, D., and Liese, W. (1971). "On the anatomy of Asian bamboos, with special reference to their vascular bundles," Wood Science and Technology 5, 290-312. DOI: 10.1007/BF00365061 
Hidayat, W., Suri, I. F., Safe'i, R., Wulandari, C., Satyajaya, W., Febryano, I. G., and Febrianto, F. (2019). "Durability and dimensional stability of hybrid particleboard of bamboo-wood with steam and hot water immersion treatment," Journal of Tropical Wood Science and Technology 17(1), 68-82.

Huang, X. Y., Qi, J. Q., Xie, J. L., Hao, J. F., Qin, B. D., and Chen, S. M. (2015). "Variation in anatomical characteristics of bamboo, Bambusa rigida," Sains Malaysiana 44(1), 17-23.

Jeon, W. S., Kim, Y. K., Lee, J. A., Kim, A. R., Darsan, B., Chung, W. Y., and Kim, N. H. (2018a). "Anatomical characteristics of three Korean bamboo species," Journal of the Korean Wood Science and Technology 46(1), 29-37. DOI: 10.5658/WOOD.2018.46.1.29

Jeon, W. S., Byeon, H. S., and Kim, N. H. (2018b). "Anatomical characteristics of Korean Phyllostachys pubescens by age," Journal of the Korean Wood Science and Technology 46(3), 231-240. DOI: 10.5658/WOOD.2018.46.3.231

Kumar, Y. B., Sharma, M., and Sharma, C. L. (2017). "Anatomical and physical properties of Bambusa mizorameana Naithani," International Journal of Advanced Research 3(4), 479-486.

Liese, W. (1980). "Anatomy of bamboo," in: Bamboo Research, Proceedings of a Workshop Held in Singapore, IDRC, Ottawa, ON, Canada, pp. 161-164.

Lobovikov, M., Ball, L., Guardia, M., and Russo, L. (2007). World Bamboo Resources, A Thematic Study Prepared in the Framework of the Global Forest Resources Assessment 2005, FAO, Viale delle Terme di Caracalla, Rome, Italy.

Marsoem, S. N., Setiaji, F., Kim, N. H., Sulistyo, J., Irawati, D., Nugroho, W. D., and Pertiwi, Y. A. B. (2015). "Fiber morphology and physical characteristics of Gigantochloa atter at three different ages and heights of culms for better utilization," Journal of the Korean Wood Science and Technology 43(2), 145-155. DOI: 10.5658/WOOD.2015.43.2.145

Maulana, S., Gumelar, Y., Fatrawana, A., Maulana, M. I., Hidayat, W., Sumardi, I., Wistara, N. J., Lee, S. H., Kim, N. H., and Febrianto, F. (2019). "Destructive and non-destructive tests of bamboo oriented strand board under various shelling ratios and resin contents," Journal of the Korean Wood Science and Technology 47(4), 519532. DOI: 10.5658/WOOD.2019.47.4.519

Mera, F. A. T. M., and Xu, C. (2014). "Plantation management and bamboo resource economics in China," Ciencia y Tecnología 7(1), 1-12. DOI: 10.18779/cyt.v7i1.137

Mustafa, M. T., Wahab, R., Sudin, M., Khalid, I., and Kamal, N. A. M. (2011). "Anatomical properties and microstructures features of four cultivated bamboo Gigantochloa species," Journal of Asian Scientific Research 1(7), 328-339.

Nordahlia, A. S., Anwar, U. M. K., Hamdan, H., Zaidon, A., Paridah, M. T., and Razak, O. A. (2012). "Effects of age and height on selected properties of Malaysian bamboo (Gigantochloa levis)," Journal of Tropical Forest Science 24(1), 102-109.

Park, S. H., Jang, J., Wistara, I., Hidayat, W., Lee, M., and Febrianto, F. (2018). "Anatomical and physical properties of Indonesian bamboos carbonized at different temperatures," Journal of the Korean Wood Science and Technology 46(6), 656-669. DOI: 10.5658/WOOD.2018.46.6.656

Park, S. H., Jang, J. H., Wistara, N. J., Febrianto, F., and Lee, M. (2019). "Fuel properties of Indonesian bamboo carbonized at different temperatures," BioResources 14(2), 4224-4235. DOI: 10.15376/biores.14.2.4224-4235 
Park, S. H., Wistara, N. J., Febrianto, F., and Lee, M. (2020). "Evaluation of sembilang bamboo (Dendrocalamus giganteus) charcoal for potential utilization," BioResources 15(1), 6-19. DOI: 10.15376/biores.15.1.6-19

Scurlock, J. M., Dayton, D. C., and Hames, B. (2000). "Bamboo: An overlooked biomass resource?," Biomass and Bioenergy 19(4), 229-244. DOI: 10.1016/S09619534(00)00038-6

Segal, L., Creely, J. J., Martin, A. E., and Conrad, C. M. (1959). “An empirical method for estimating the degree of crystallinity of native cellulose using the X-ray diffractometer," Textile Research Journal 29, 786-794. DOI: 10.1177/004051755902901003

Siam, N. A., Uyup, M. K. A., Husain, H., and Awalludin, M. F. (2019). “Anatomical, physical, and mechanical properties of thirteen Malaysian bamboo species," BioResources 14(2), 3925-3943. DOI: 10.15376/biores.14.2.3925-3943

SNI 8020:2014 (2014). "Bamboo uses,” National Standardization Agency, Jakarta, Indonesia.

Wahab, R., Mustapa, M. T., Sulaiman, O., Mohamed, A., Hassan, A., and Khalid, I. (2010). "Anatomical and physical properties of cultivated two-and four-year-old Bambusa vulgaris,” Sains Malaysiana 39(4), 571-579.

Wang, Y., Leppänen, K., Andersson, S., Serimaa, R., Ren, H., and Fei, B. (2012). "Studies on the nanostructure of the cell wall of bamboo using X-ray scattering," Wood Science and Technology 46(1-3), 317-332. DOI: 10.1007/s00226-011-0405-3

Widjaja, E. A., Rahayuningsih, Y., Ubaidillah, R., Maryanto, and Rahajoe, J. S. (2014). The Present Indonesian Biodiversity, LIPI Press, Jakarta, Indonesia.

Article submitted: January 15, 2021; Peer review completed: March 14, 2021; Revised version received and accepted: March 24, 2021; Published: March 30, 2021.

DOI: $10.15376 /$ biores.16.2.3596-3606 